\title{
Synthetic fatty acid from crude oil of Tamsagbulag petroleum deposit (Mongolia)
}

\author{
Myagmargerel Bayanmunkh, Khulan Bayasgalan*, Gantsetseg Byambasuren, \\ Khongorzul Batchuluun, Tuya Murneren \\ Institute of Chemistry and Chemical Technology, Mongolian Academy of Sciences, Ulaanbaatar 13330, Mongolia
}

${ }^{*}$ Corresponding author: khulanb@mas.ac.mn; ORCID iD: 0000-0002-2438-9757

Received: 27 April 2021; revised: 29 June 2021; accepted: 29 June 2021

\begin{abstract}
In this work, we studied to obtain synthetic fatty acids raw materials to produce surfactants and various detergents from paraffin. The solid paraffin extracted from the Tamsagbulag petroleum deposit was 46 mass $\%$, distilled $350-450{ }^{\circ} \mathrm{C}$, by complexing with urea. Experimental study indicates paraffin's physicochemical characteristics from this petroleum are more suitable to use in the production of synthetic fatty acids. By solid paraffin oxidation, we obtained $33.01 \%$ of the synthetic fatty acids containing monocarboxylic acids. We suggest obtaining the synthetic fatty acid by oxidation process in normal condition from petroleum paraffin.
\end{abstract}

Keywords: Synthetic fatty acid, solid paraffin, crude oil, oxidation, petroleum

\section{INTRODUCTION}

Crude oil, one of the most complex chemical mixtures in the world, serves as a feedstock for the petrochemical industry and as raw material for many chemical products such as fuels, solvents, lubricant oils, plastics, fertilizers, detergents, and others [1, 2]. There are some deposits of crude oil in our country. Out of them, 3 large deposits are being exploited. The Tamsagbulag deposit is located in the Matad area of Dornod province, Mongolia. Other deposits such as Zuunbayan and Tsagan - Els are situated in the Zuunbayan area Dornogovi province, with 332.67 million tons of proven oil reserves and 43, 25 million tons of proven reserves [3, 4, 5]. Previously, we studied the physicochemical properties of petroleum and the detail of the complete hydrocarbon composition of crude oils from the Tsagaan - Els, Zuunbayan, and Tamsagbulag deposits. Based on the previous report, the crude oil of Mongolia was determined as heavy oil with high viscosity and has a lower yield of light fraction, and it belongs to the high-paraffinic category of crude oil [3, $6,7]$. One of a kind products obtained from the high paraffin crude oil is a synthetic fatty acid. Synthetic fatty acids are critical raw materials for soaps, detergents, fragrances, emulsifiers, organic lubricating oils, and surfactants, which can be obtained by oxidation of paraffin-rich crude oil. During the oxidation process,
$70 \%$ of the high molecular monocarboxylic acids can be produced by the oxidation of solid paraffin to manufacture aliphatic alcohols and surfactants, and the remaining $30 \%$ consume for lubricants $(15 \%)$ and in other industries [1, 8, 9]. For over some years, various researchers have studied the air oxidation of paraffinic hydrocarbons to produce synthetic fatty acids [1, 8]. In the previous research, based on the high-paraffin crude oil in the field of Tsagaan - Els, solid paraffin was extracted from the oil fraction and further oxidized by molecular oxygen the in the presence of a catalyst to produce synthetic fatty acids [10]. Tsagaan - Els crude oil deposit has a lower reserve than the Tamsagbulag oil deposit. Moreover, it contains low asphaltene, low oil, and high water content than the Tamsagbulag oil deposit [10]. Since the Tamsagbulag and Tsagaan - Els deposit crude oil show different physical and chemical characteristics, it's evident that the technological scheme for obtaining synthetic fatty acid is expected to be different. At the same time, the development of petrochemical synthesis technology from various petroleum sources in Mongolia is an important study. It has practical significance in creating opportunities for domestic goods production. In this work, we aimed at the possibility of isolating synthetic fatty acid from solid paraffin from the Tamsagbulag crude oil deposit and studied its properties. 


\section{EXPERIMENTAL}

Materials: As a research sample of crude oil from the depth of $2300-2600 \mathrm{~m}$ in the XXI block of Eastern of Tamsagbulag field Mongolia, which had brought at September 2018 year, was used. The petroleum exploration blocks in Mongolia and sample collected area are shown in Fig. 1.

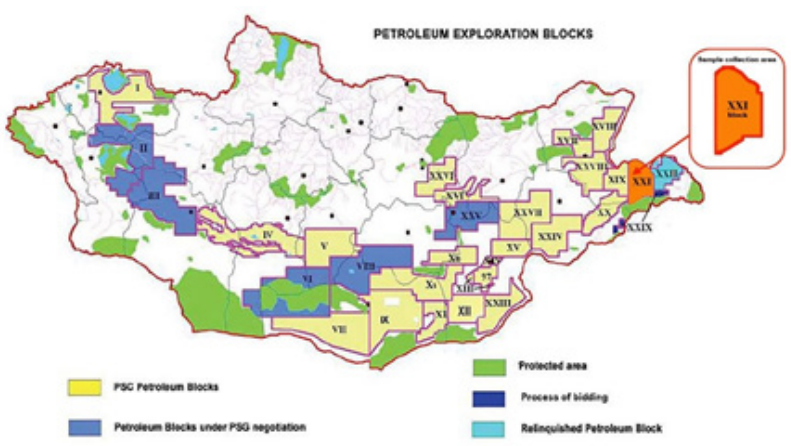

Fig. 1. Petroleum exploration blocks in Mongolia and sample collected area

Experimental procedures: Physical characteristics (density, viscosity, and flash point) and fractional composition were determined according to Petroleum Analysis standard methods [2, 11, 12]. SARA method is used for group composition (oil, resin, and asphaltenes) of crude oil [2, 13, 14]. Experimental to isolate synthetic fatty acids from petroleum were carried out according to the following scheme.

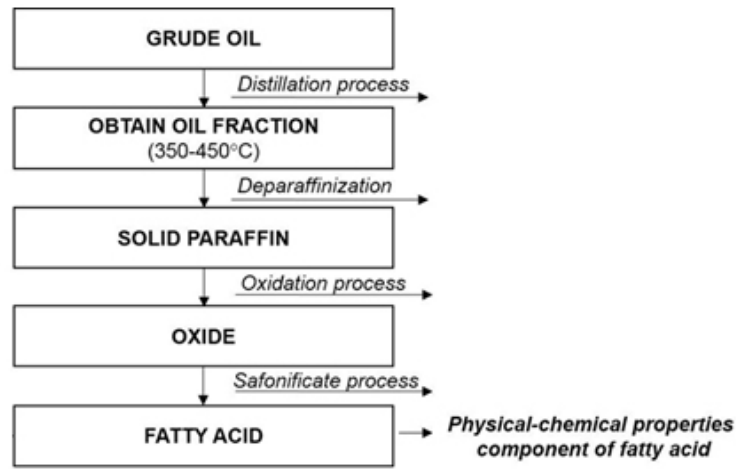

Fig. 2. Scheme of obtaining fatty acid from Tamsagbulag crude oil

Through forming a complex of urea, solid paraffin was extracted from the oil fraction, which is distilled at 350 - $450{ }^{\circ} \mathrm{C}$, and the structure and properties of obtained solid paraffin have been determined $[1,15,16]$.

The oxidation of paraffin was carried out in the liquid phase by molecular oxygen in the presence of catalysts such as permanganates $\left(\mathrm{KMnO}_{4}\right)$, temperatures in the range of about 105 to $130{ }^{\circ} \mathrm{C}$, and under atmospheric pressure. The FT-IR spectra of oxide products were obtained on a Nicolet 20 - PC FT-IR spectrometer with Csl optics and a DTGS detector. The $\mathrm{KBr}$ disc contained a $0.5 \%$ finely ground shell sample. All the spectra were measured with a frequency range of 4000 to $400 \mathrm{~cm}^{-1}$ and 32 scans for each sample [17, 18].

The hydrocarbon's composition of obtained synthetic fatty acids and paraffin of petroleum studied by gas chromatography-mass spectrometer as Thermo Scientific-Trace 1310 GC-MS with the detector of TSQ8000-triple Quandrupole MS and column of TR5MS $60 \times 02 \mathrm{~mm}(\mathrm{D} \times 0.25 \mu \mathrm{m})$ using under $1.5 \mathrm{ml} /$ min speed of helium gas [19-22].

\section{RESULTS AND DISCUSSION}

The physical and chemical characteristics, group composition, and content of fraction of the petroleum of Tamsagbulag deposit of Mongolia have been studied. The physical and chemical characteristics of the oil are given in Table 1.

Table 1. The physical and chemical characteristics of Tamsagbulag oil

\begin{tabular}{ll}
\hline Characteristics of crude oil & Tamsagbulag oil \\
\hline Appearance & Thick and black color \\
\hline Specific gravity, $50{ }^{\circ} \mathrm{C}, \mathrm{kg} / \mathrm{m}^{3}$ & 839 \\
\hline Kinematic viscosity, $\mathrm{mm} / \mathrm{sec}, 50^{\circ} \mathrm{C}$ & 22.5 \\
\hline Flashpoint, in open crucible, ${ }^{\circ} \mathrm{C}$ & 62 \\
\hline Freezing point, ${ }^{\circ} \mathrm{C}$ & 18 \\
\hline Group composition, wt $\%$ & \\
\hline Resins & 10.99 \\
\hline Asphaltenes & 0.98 \\
\hline Oil (saturate and aromatics) & 88.03 \\
\hline Solid paraffin in the oil & 17.8 \\
\hline The yield of fuel fraction, $\%$ & \\
\hline Boiling point, ${ }^{\circ} \mathrm{C}$ & 52 \\
\hline Gasoline (Start boiling to - $\left.250{ }^{\circ} \mathrm{C}\right)$ & 17.63 \\
\hline Diesel (250 - $350{ }^{\circ} \mathrm{C}$ ) & 14.85 \\
\hline Oil (Lub) fraction $\left(350-450{ }^{\circ} \mathrm{C}\right)$ & 30.62 \\
Vacuum residue $\left(>450{ }^{\circ} \mathrm{C}\right)$ & 36.9 \\
\hline
\end{tabular}

Table 1 shows Tamsagbulag petroleum is a high viscosity and high flash point. The yield of light fractions of petroleum is low, leading to an increase in flash temperature. The high temperature of the flash point of this oil is directly related to the high boiling point. The high paraffin content also leads to high viscosity and freezing points. From the previous references, high paraffin content crude oils from Karaganda (Kazakhstan), and White tiger (Vietnam) deposits show viscosity at $20{ }^{\circ} \mathrm{C} 13.55,17.52 \mathrm{~mm}^{2} / \mathrm{sec}$, respectively $[23,24]$. But, Tamsagbulag crude oil's viscosity at $50^{\circ} \mathrm{C}$ was $22.5 \mathrm{~mm}^{2} / \mathrm{sec}$. Although Karaganda and White tiger crude oils show near paraffin contents to Tamsagbulag oil, their viscosity varies largely. $\mathrm{C}_{21}-\mathrm{C}_{30} n$-alkanes content of the Tamsagbulag oil is considered to be high, while the crude oil from the White tiger contains a low number of $\mathrm{C}_{21}-\mathrm{C}_{35}$ alkanes and a high amount of light $\mathrm{C}_{10}-\mathrm{C}_{20}$, respectively. The high number of $\mathrm{C}_{20}-\mathrm{C}_{34}$ 
alkanes of the Tamsagbulag crude oil was caused by its high viscosity $[23,25]$. The viscosity, flash temperature, and fuel fraction of the Mongolian other petroleum deposits (Zuunbayan and Tsagaan-Els) were shown the same trend as the Tamsagbulag deposit $[3,6,7$, 26]. In other words, Mongolian crude oils are having high density, high flash point, and low fuel fraction than other foreign deposits with the same paraffin content. The oil (lub) fraction's content was determined as $30.62 \%$ in Tamsagbulag oil, and the oil fraction was viscous and mainly composed of hydrocarbons of paraffin. Therefore, chemical synthetic products can be produced based on the raw materials of the above oil fraction and are economically effective. Urea forms a crystalline complex with alkanes with at least 6 carbon atoms $\left(>\mathrm{C}_{6}\right)$ in straight-chain paraffin or more hydrocarbon atoms obtained at room temperature and under normal pressure. Straight-chain alkanes are dominated in the petroleum oil fraction $\left(300-400{ }^{\circ} \mathrm{C}\right)$ and have a high ability to form urea complexes under normal conditions [27, 28]. According to our results, iso-octane is more selective in the process of forming a complex with urea in the oil fraction. The best conditions for separating paraffin can be described as the oil fraction: iso-octane $1: 5$, oil fraction: urea $1: 4$, urea: activator (ethanol) $1: 4[27,28]$. In this case, the yield of solid paraffin separated from the oil fraction of the Tamsagbulag deposit was $46.0 \%$. The characteristics of solid paraffin from the oil fraction of the Tamsagbulag deposit have been shown in Table 2.

Table 2. Characteristics of solid paraffin extracted from Tamsagbulag oil

\begin{tabular}{|lll}
\hline Characteristics & $\begin{array}{l}\text { Solid } \\
\text { paraffin }\end{array}$ & $\begin{array}{l}\text { Petroleum } \\
\text { paraffin C type, } \\
\text { GOST 23683 }\end{array}$ \\
\hline Appearance & $\begin{array}{l}\text { White and } \\
\text { hard }\end{array}$ & White and hard \\
\hline Odor & odorless & odorless \\
\hline Yield, $\%$ & 46.0 & - \\
\hline Specific gravity, $\mathrm{g} / \mathrm{cm}^{3}$ & 0.84 & - \\
\hline Melting point, ${ }^{\circ} \mathrm{C}$ & 52 & $45-52$ \\
\hline Freezing point, ${ }^{\circ} \mathrm{C}$ & 44.2 & - \\
\hline Temperature, ${ }^{\circ} \mathrm{C}$ & & \\
\hline $5 \%$ distillation temperature, ${ }^{\circ} \mathrm{C}$ & 355 & $>320$ \\
\hline Distillation up to $400{ }^{\circ} \mathrm{C}, \%$ & 60 & $>60$ \\
\hline Distillation up to $415{ }^{\circ} \mathrm{C}, \%$ & 80 & $>80$ \\
\hline $97 \%$ distillation temperature, ${ }^{\circ} \mathrm{C}$ & 445 & $>460$ \\
\hline Number of carbon atoms & $\mathrm{C}_{20}$ - $\mathrm{C}_{34}$ & - \\
\hline Content of $n$-alkanes, $\%$ & 83.12 & - \\
\hline Content of oil, $\%$ & 2.2 & $<2.3$ \\
\hline
\end{tabular}

Table 2 shows that the physicochemical characteristics of paraffin wax obtained from the oil fraction of this oil are classified as C-type paraffin, which can be used to produce synthetic fatty acids [27, 29].
The content and distributions of the $n$-alkanes composition of paraffin, separated from Tamsagbulag's oil, were determined by gas chromatography and are shown in Figs. 3, 4.

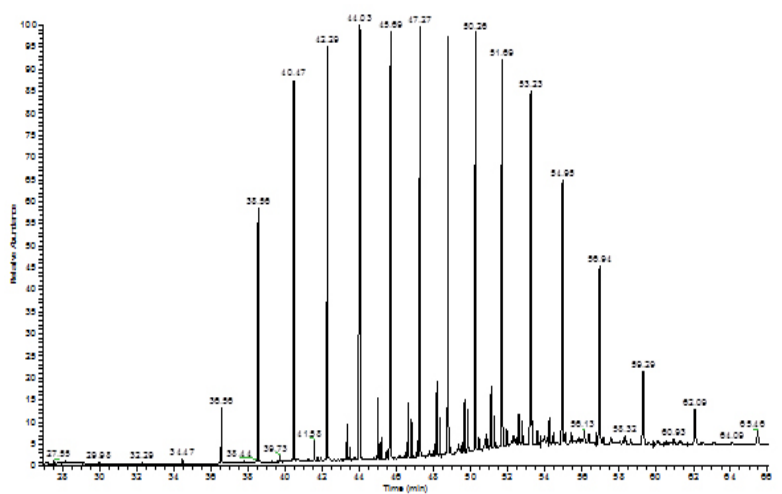

Fig. 3. GC analysis of $n$-paraffin obtained from oil the fraction in Tamsagbulag's oil

The paraffin obtained from Tamsagbulag oil contains $n$-alkanes of $83.12 \%$ with carbon atoms $C_{20}-C_{34}$. If the purity of paraffin is insufficient and the branched alkane content is high, the oxidation process of paraffin to fatty acid is adversely affected. German scientists investigated the solid paraffin of petroleum $\left(\mathrm{C}_{20}-\mathrm{C}_{35}\right)$ oxidized into fatty acid from lauric acid to stearic acid. Therefore, we used this method which is more suitable to get fatty acid into the general raw material of synthetic soup, washing detergent [1, 31].

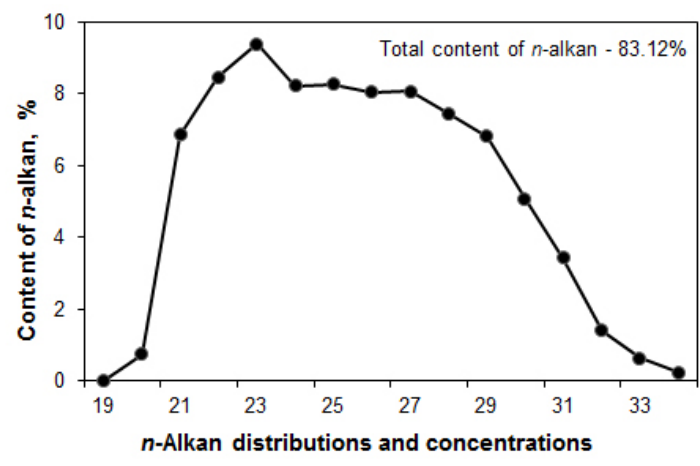

Fig. 4. n-Alkane distribution of Tamsagbulag crude oil

Fig. 4 specifies that the paraffin obtained from Tamsagbulag deposit oil is a suitable raw material for the production of synthetic fatty acids. Paraffin molecule oxidation with oxygen and obtaining synthetic fatty acids is a complex reaction controlled by a radical chain reaction mechanism in the liquid phase [1, 31]. Obtaining synthetic fatty acids with the reaction of paraffin oxidation depends directly on the reaction parameters such as temperature, pressure, catalyst, and oxygen flow. When the oxidation of paraffin is carried out at temperatures above $120^{\circ} \mathrm{C}$, it forms large quantities of low molecular weight fatty acids -oxyacids, dicarboxylic acids, and other related products like a mixture various oxygen compounds [32, 33]. 
Under suitable conditions for synthetic fatty acids, the product yield formed high, and the by-product is less developed. Therefore, it is necessary to select the appropriate conditions and carry out the reaction. In determining the best oxidizing condition of paraffin, the catalyst value was changed between $0.3-1.5 \%$, oxygen flow $0.5-4.5 \mathrm{~L} / \mathrm{min}$, temperature $105-160{ }^{\circ} \mathrm{C}$ [10, 33].

As the result of oxidation of paraffin of Tamsagbulag's oil is tested several times in the temperatures range of about 105 to $130{ }^{\circ} \mathrm{C}$ with a $0.6 \mathrm{~L} / \mathrm{min}$ oxygen flow in the oxidizing reactor, as the following conditions are selected as the best. It is considered that the amount of catalyst will be 0.3 mas. $\%[1,10,34]$. In the early stages of the oxidation of paraffin, we carried out the reaction at relatively high temperatures $\left(120-130{ }^{\circ} \mathrm{C}\right)$ for $2 \mathrm{~h}$ to form free radicals and stimulate the faster reaction. During the process, the catalyst dissolves in paraffin and stimulates an oxidation reaction. In the second stage of the reaction, the temperature was gradually down to $105-110{ }^{\circ} \mathrm{C}$, and $0.6 \mathrm{~L} / \mathrm{min}$ flow rate of molecular oxygen was entered, and then an oxidation reaction takes place. During this process, the paraffin-free radicals are oxidized by oxygen, the byproduct is minor at relatively low temperatures, and the reaction takes place in the direction of the formation of fatty acids [33, 34].

As a result of the oxidation of $n$-paraffin, a mixture of acidic and neutral oxygenated compounds is formed. The amount of these compositions is controlled by the value of acid.

Generally, the value of acid varies from 70 to $76 \mathrm{mg}$ $\mathrm{KOH} / \mathrm{g}$ when synthetic fatty acid is oxidized [1, 31]. It shows that the number of oxidizing acids was 74 $\mathrm{mg} \mathrm{KOH} / \mathrm{g}$ when the solid paraffin of petroleum of Tamsagbulag is oxidized under these conditions for $30 \mathrm{~h}$, and paraffin's hydrocarbons are oxidized to form fatty acids.

The dependence between the oxidation period of paraffin and the number of acids is shown in Fig. 5. Oxidation is high as the number of acids increases, and it is linearly related to the oxidation period.

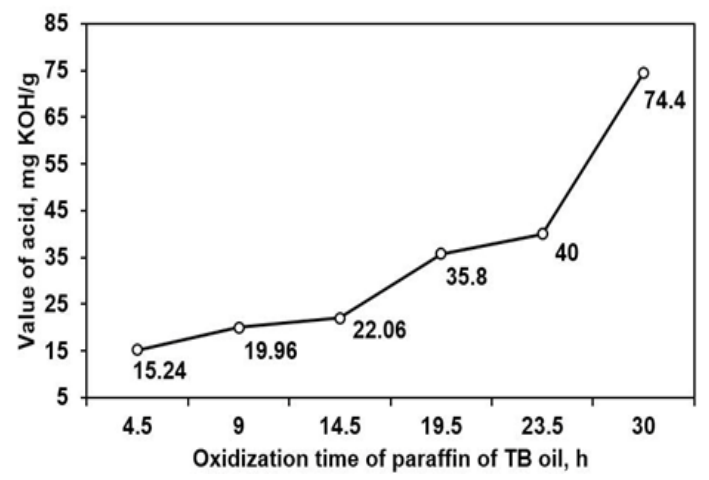

Fig. 5. Dependence of value acid and oxidation time of solid paraffin
The structure of the hydrocarbons in the composition of paraffin and oxidized products of Tamsagbulag's oil was determined by IR spectroscopy and are shown in Fig. 6.
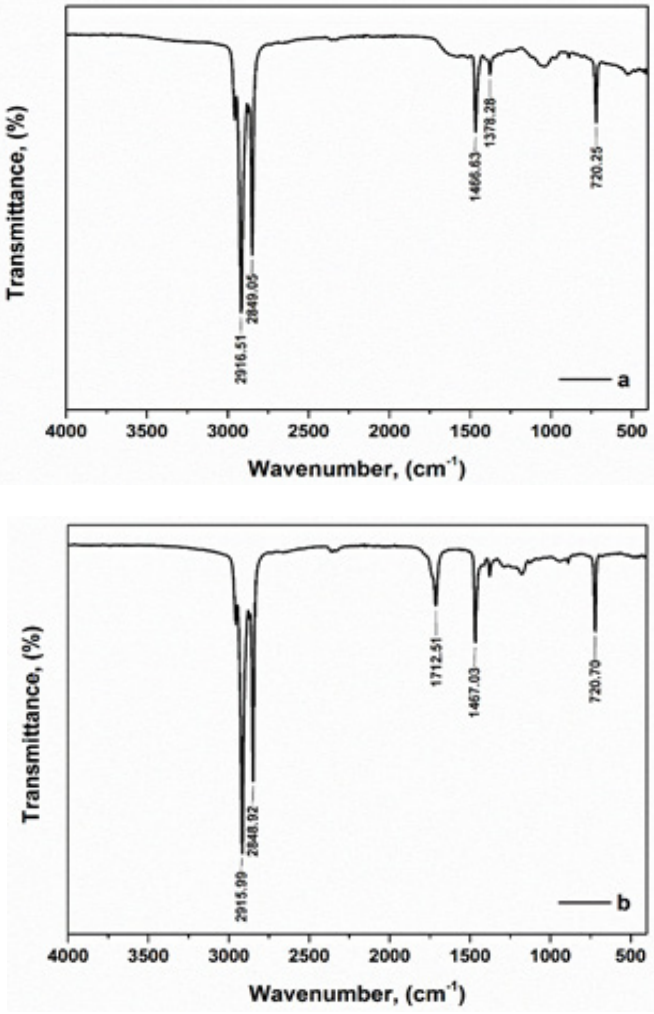

Fig. 6. IR spectrum. a-paraffin, b-oxidate of the Tamsagbulag oil

IR analysis for both the paraffin and oxidized paraffin showed characteristic bands at 2850 - 2916, 1467, and $720 \mathrm{~cm}^{-1}$. The bands are $\mathrm{CH}$ - aliphatic, $-\mathrm{CH}_{3}$ - methyl, and methylene $-\left(\mathrm{CH}_{2}\right)$. The IR spectrum of the oxidized product shows the intensive absorption of a carboxylic acid group ( $-\mathrm{R}-\mathrm{COOH})$ at $1710 \mathrm{~cm}^{-1}[17,18]$.

IR spectral analysis confirmed that the paraffin obtained from Tamsagbulag's oil had been oxidized by the flow of oxygen in the presence of a catalyst to the fatty acid. The low molecular acids were separated from other mixtures by washing hot distilled water and saponified by $\mathrm{Na}_{2} \mathrm{CO}_{3}$ and alkali solution, distilled under $140-260$ ${ }^{\circ} \mathrm{C} / 2 \mathrm{~mm} \mathrm{Hg}$ pressure. Generally, after synthetic fatty acid is formed, the raw material of fatty acids $\left(C_{10}-C_{20}\right)$ is used to manufacture soap [1].

Table 3. The property of fatty acid obtained from Tamsagbulag oil

\begin{tabular}{ll}
\hline Properties & Fatty acid \\
\hline Yield, \% & 33.01 \\
Acid value, $\mathrm{mg} \mathrm{KOH} / \mathrm{g}$ & 254 \\
Saponification value, $\mathrm{mg} \mathrm{KOH} / \mathrm{g}$ & 260.0 \\
Ester value, $\mathrm{mg} \mathrm{KOH} / \mathrm{g}$ & 6.2 \\
\hline
\end{tabular}

The ester value is between $5-10 \mathrm{mg} \mathrm{KOH} / \mathrm{g}$, and the saponification value is $245-260 \mathrm{mg} \mathrm{KOH} / \mathrm{g}$, and the acid 
value is $245-260 \mathrm{mg} \mathrm{KOH} / \mathrm{g}[1,31]$. The parameters of the extracted fatty acids were determined and shown in Table 3.

From the Table 4, according to the parameters of synthetic fatty acids obtained by oxidizing petroleum paraffin from the Tamsagbulag deposit, the acids value is $254 \mathrm{mg} \mathrm{KOH} / \mathrm{g}$, the esters value is $6.2 \mathrm{mg} \mathrm{KOH} / \mathrm{g}$, and the saponification value is $260.0 \mathrm{mg} \mathrm{KOH} / \mathrm{g}$. It indicates that fatty acids are formed as a result of the oxidation process.

The chemical composition of the fatty acid obtained by paraffin oxidation was determined by gas chromatography, and the results are shown in Fig. 7 and Table 4.

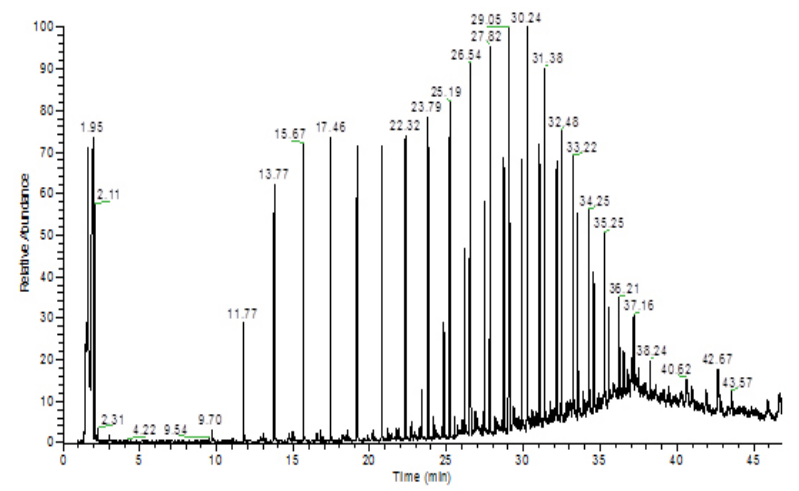

Fig. 7. GC analysis of synthetic fatty acids of oxidized paraffin of Tamsagbulag oil

As shown in Table 4, the composition of synthetic fatty acids obtained by the oxidation of petroleum paraffin contains synthetic fatty acids with carbon atoms $\mathrm{C}_{7}-\mathrm{C}_{20}$ with a variation of content $0.2-3.5 \%$.

Table 4. Chemical composition of fatty acid from paraffin of Tamsagbulag oils

\begin{tabular}{lllc}
\hline Fatty acids & $\begin{array}{l}\text { Chemical } \\
\text { formula }\end{array}$ & $\begin{array}{c}\text { Content, } \\
\%\end{array}$ & $\begin{array}{c}\text { Retention } \\
\text { time, min }\end{array}$ \\
\hline Enanthic acid & $\mathrm{C}_{6} \mathrm{H}_{13} \mathrm{COOH}$ & 0.24 & 7.15 \\
Caprylic acid & $\mathrm{C}_{7} \mathrm{H}_{15} \mathrm{COOH}$ & 1.1 & 9.07 \\
Pelargonic acid & $\mathrm{C}_{8} \mathrm{H}_{17} \mathrm{COOH}$ & 2.1 & 10.92 \\
Capric acid & $\mathrm{C}_{9} \mathrm{H}_{19} \mathrm{COOH}$ & 2.74 & 12.68 \\
Undecanoic acid & $\mathrm{C}_{10} \mathrm{H}_{21} \mathrm{COOH}$ & 3.15 & 14.36 \\
Lauric acid & $\mathrm{C}_{11} \mathrm{H}_{23} \mathrm{COOH}$ & 3.47 & 15.94 \\
Tridecylic acid & $\mathrm{C}_{12} \mathrm{H}_{25} \mathrm{COOH}$ & 3.41 & 17.44 \\
Myristic acid & $\mathrm{C}_{13} \mathrm{H}_{27} \mathrm{COOH}$ & 3.33 & 18.86 \\
Pentadecanoic acid & $\mathrm{C}_{14} \mathrm{H}_{29} \mathrm{COOH}$ & 3.32 & 20.22 \\
Palmitic acid & $\mathrm{C}_{15} \mathrm{H}_{31} \mathrm{COOH}$ & 2.97 & 21.51 \\
Margaric acid & $\mathrm{C}_{16} \mathrm{H}_{33} \mathrm{COOH}$ & 2.54 & 22.75 \\
Stearic acid & $\mathrm{C}_{17} \mathrm{H}_{35} \mathrm{COOH}$ & 1.9 & 23.93 \\
Nonadecylic acid & $\mathrm{C}_{18} \mathrm{H}_{37} \mathrm{COOH}$ & 1.36 & 25.06 \\
Arachidic acid & $\mathrm{C}_{19} \mathrm{H}_{39} \mathrm{COOH}$ & 0.88 & 26.14 \\
Heneicosylic acid & $\mathrm{C}_{20} \mathrm{H}_{41} \mathrm{COOH}$ & 0.5 & 27.19 \\
\hline The total content of fatty acids $\left(\mathrm{C}_{6}-\mathrm{C}_{20}\right)$ & \multicolumn{2}{c}{33.01} \\
Content of non-oxidized paraffin $\left(\mathrm{C}_{9}-\mathrm{C}_{23}\right)$ & \multicolumn{2}{c}{49.45} \\
Other compounds & & \multicolumn{3}{c}{17.54} \\
\hline
\end{tabular}

In a mixture of synthetic fatty acids extracted from petroleum paraffin at the Tamsagbulag deposit, the monocarboxylic acids are 33.01 and $49.45 \%$ of nonoxidized paraffin hydrocarbons, and the content of other oxygen compounds is $17.54 \%$. As a result of this study, it has been determined that the oxidation of petroleum paraffin at an oxygen flow rate of $0.6 \mathrm{~L} / \mathrm{min}$ at a variable temperature of $130-105{ }^{\circ} \mathrm{C}$, with the presence of $0.3 \%$ catalyst $\left(\mathrm{KMnO}_{4}\right)$, is the optimal condition of reaction.

Although it has been considered that the paraffin's hydrogen carbons are inactive and require a unique condition for the chemical synthesis, the present research indicated that the paraffin from the Tamsagbulag oil can be processed to form synthetic fatty acid without using special requirements.

\section{CONCLUSIONS}

It has been determined that $46 \%$ paraffin can be obtained by forming a complex of urea, solid paraffin extracted from the oil fraction of Tamsagbulag oil distilled at $350-450{ }^{\circ} \mathrm{C}$, and it belongs to the technical category $\mathrm{C}$ type used in the production of synthetic fatty acids.

Our study has indicated that the superior fatty acid, which is a raw material for surfactants, can be obtained by oxidizing petroleum paraffin hydrocarbons with oxygen under normal conditions of the oxygen flow rate of 0.6 $\mathrm{L} / \mathrm{min}$ at a variable temperature of $130-105^{\circ} \mathrm{C}$, with the presence of $0.3 \%$ catalyst $\left(\mathrm{KMnO}_{4}\right)$. The obtained fatty acid's total content of fatty acids $\left(C_{7}-C_{20}\right)$ is $33.01 \%$, and the content of non - oxidized paraffin $\mathrm{C}_{7}-\mathrm{C}_{20}$ is $49.45 \%$.

\section{REFERENCES}

1. Azinger F. (1959) Chemistry and technology of paraffinic hydrocarbons. Gostoptehizdat, Moscow, 432-480 (In Russian).

2. Santos J.M., Alessandro Vetere A., Wisniewski A., Eberlin M.N., et al. (2020) Modified SARA method to unravel the complexity of resin fraction(s) in crude oil. Ener. Fuel, 34, 16006-16013.

https://doi.org/10.1021/acs.energyfuels.0c02833

3. Khongorzul B., Golovko A.K., Gorbunova L.V., Kamyanov V.F., Purevsuren B. (2007) Mongolian crude oil. Rational refining directions. J. Chem. Tech. Fuel Oil, 43 (6), 495-502. https://doi.org/10.1007/s10553-007-0086-7

4. Oil exploitation and mining. (2020) https://mrpam. gov.mn/article/49/ (Accessed December 2020).

5. Ochirbat P. (2013) A new generation of Mongolian oil exploration. Ulaanbaatar, 40-130 (In Mongolian).

6. Sugimoto Y., Horie Y., Saotome Y., Tserendorj T., Byambajav E. (2012) Properties, chemical compositions and hydrotreatment reactivities of Mongolian crude oils. J. Japan Pet. Inst., 55(6), 363-370. 
https://doi.org/10.1627/jpi.55.363

7. Shirchin B., Nordov E., Monkhoobor D., Tuya M., Sainbayar A., et al. (2003) A study on main physical and chemical characteristics of East Mongolian petroleum. J. Korean Ind. Eng. Chem., 14(4), 423-425.

8. Purohit S. J., Pradhan M. (2013) Paraffin oxidation studies. J. Eng. Innov. Res., 2(1), 75-81.

9. Galimov R.A., Gaifullin A.A., Kharlampidi Kh.E. (2007) Oxidation of alkan for fatty acids. Kazan State Tech. Uni. Press, Kazan, 84-126 (In Russian).

10. Gantsetseg B., Khongorzul B., Khulan B., Myagmargerel B., Tuya M. (2019) Results of oxidation of solid paraffin of crude oil. Bull. Mon. Uni. Sci. Tech., 30(258), 78-81.

11. Bogomolov A.I., Temyanko M.B., Khotyntseva L.I. (1984) Modern method of oil study. Nedra, Leningrad, 50-210 (In Russian).

12. Monkhoobor D. (2003) Method of analysis of petroleum and petroleum products. NUM press. Ulaanbaatar, 15-85 (In Mongolian).

13. Khongorzul B., Kamyanov V.F. (2007) Functional group composition of ingredients of Mongolian oils. J. Chem. Sustainable Dev., 15, 489-494.

14. Golovlo G., Pevneva G.S., Kamiyanov V.F., Jovancicevic B., et al. (2004) Saturated hydrocarbons in mezozonic oils from Mongolia. Pet. Chem., 44(6), 395-402.

15. Ganieva T.F., Fakhrutdinov R.Z., Bashkirtseva N.Yu. (2017) Fuels and oils. Methods for improving their operational properties. Prospect Nauki, Sankt-Peterburg, 5-28 (In Russian).

16. Khulan B., Bembeli B.M., Golovko A.K., Shirchin B. (2007) Deparaffinzation of heavy fractions of high paraffins crude oils. J. Treat. Pet. Pet. Chem., 7, 28-31.

17. Tarasevich. B.N. (2012) IR spectra of the main classes of organic substances. MGU press, Moscow, 4-25 (In Russian).

18. Monkhoobor D., Batchimeg G. (2009) Structure of molecule and spectroscopy. NUM Press, Ulaanbaatar, 31-95 (In Mongolian).

19. Seppanen-Laakso T., Laakso I., Hiltunen R. (2002) Analysis of fatty acids by gas chromatography, and its relevance to research on health and nutrition. J. Anal. Chim. Acta, 465(1-2). 39-62. https://doi.org/10.1016/S0003-2670(02)00397-5

20. Odebunmi E.O., Ogunsakin E.A., Ilukhor P.E.P. (2002) Characterization of crude oils and petroleum products: (I) Elution liquid chromatographic separation and gas chromatographic analysis of crude oils and petroleum products. Bull. Chem. Soc. Ethiop., 16(2), 115-132.

21. Blomberg J., Schoenmakers P.J., Brinkman U.A.T. (2002) Gas chromatographic methods for oil analysis. J. Chromatography, 972(2), 137-173. https://doi.org/10.1016/S0021-9673(02)00995-0
22. Kim E., Cho E., Moon C., Ha J., Cho E. et al. (2016) Correlation among petroleomics data obtained with high-resolution mass spectrometry and elemental and NMR analyses of maltene fractions of atmospheric pressure residues. J. Ener. Fuel, 30, 6958-6967. https://doi.org/10.1021/acs.energyfuels.6b01047

23. Aliev N.U., Sahatova G.C. (2012). Paraffinic oils of Kenkiyak and Karaganda deposits and individual composition of their gasoline. Bull. Tom. Univ., 321(3), 175-178.

24. Nguyen D.T., Larionov S.V., Grishina I.N., Vinokurov V.A. (2018) Study of the rheological properties of highly paraffinic oils for pipeline. J. Oil Gas Tech., 117(4), 4-5.

25. Serebrennikova O.V., Wu W.H., Savinykh Yu.V., Krasnoyarova. A. N. (2012) Oil genesis of the white tiger field (Vietnam) according to the data on the composition of saturated acyclic hydrocarbons. Bull. Tomsk Pol. Univ., 320(1), 134-137.

26. Davaatseren B. (2008) The changes of composition and properties of high paraffin oils by processing non-traditional methods. PhD thesis, Institute of petroleum chemistry, Tomsk, Russia.

27. Khulan B., Bolormaa B., Myagmargerel B., Ulzii B., Tuya M. (2012) Obtain of solid paraffin from high paraffin crude oil of Mongolia. Abst. Petroleum chemistry and gas. 2004, Russia, Tomsk, 787. https://doi.org./10.17223/9785946217408/534

28. Usachev B.B. (1967) Deparaffinzation by urea. Khimiya press, Moscow, 23-58 (In Russian).

29. Standard. Petroleum paraffin waxes. GOST 23683-89.

30. Lange K.R. (1999) Surfactants. A Practical Handbook. Hanser, Munich, 237.

31. Kuznetsova I.M., Cherkunov E.V. (2011) Development of the technology of heterogeneous reaction in the gas-liquid system. Book of laboratory practice in chemical technology. Kazan State Tech. Univ. press, Kazan, 9-18.

32. Cong Y., Huang W. (2010) Study on kinetics of paraffin-catalyzed oxidation reaction. J. Pet. Sci. Tech., 28(4), 393-400. https://doi.org/10.1080/10916460903070728

33. Khulan B., Myagmargerel B., Khongorzul B., Gantsetseg B., Tuya M. (2019) Study of fatty acid from Tamsagbulag oil. Book of Abstracts. Chemistry-2020, 37.

34. Liao K., Cong Y., Kang L., Deng X.-Q. (2008) The mechanism of paraffin oxidation. J. Pet. Sci. Tech., 26(15). 1852-1858. https://doi.org/10.1080/10916460701426056 